\title{
Cidades Antigas Edilícia Nova ${ }^{\mathrm{NT} 1}$ \\ Roberto Pane
}

Tradução: Nivaldo Andrade ${ }^{\mathrm{NT} 2}$

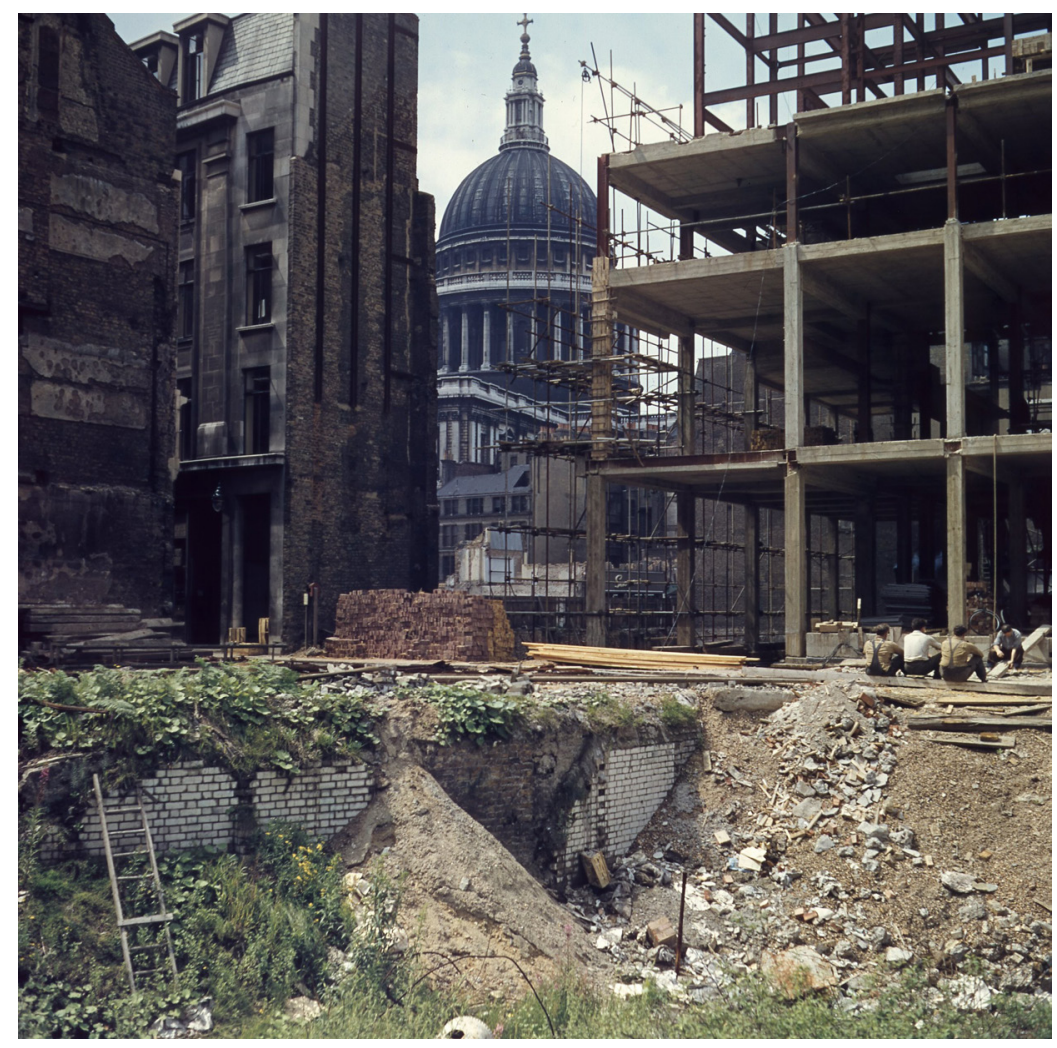

Figura 01

Reconstrução da City de Londres, vendo-se a Catedral de Saint Paul ao fundo. Foto de Roberto Pane, década de 1960. Arquivo fotográfico Roberto Pane, Dipartimento di Architettura, Università degli Studi di Napoli Federico II, por cortesia de Andrea Pane.

Este breve escrito foi apresentado por mim no congresso nacional de urbanismo, realizado em Turim em outubro de 1956. Meu objetivo era reunir, em uma rápida síntese, os assuntos mais recorrentes na atual problemática dos centros antigos para estabelecer alguma premissa útil aos debates que ainda estão se desenvolvendo.

A imagem do mundo que se reflete na edilícia é suficiente para conduzir os arquitetos e os escritores de cada país a participar das questões relativas à sobrevivência dos antigos centros e, em particular, daqueles italianos; não apenas porque o nosso é um precioso patrimônio comum, mas porque, nas formas da nova edilícia e na possibilidade de uma sua convivência com aquelas do passado, se configura, no seu porvir e de maneira exemplar, a marca do nosso próprio destino. ${ }^{\mathrm{NT3}}$ 
1 Aludo em particular aos escritos de Antonio Cederna, publicados na revista Il Mondo, e a um artigo de Cesare Brandi, do qual falarei mais adiante.
Q uando pensamos em uma justaposição entre a edilícia moderna e a antiga, sentimos de imediato despertarem em nós muitos problemas e questionamentos; e isso especialmente na Itália, onde, mais do que em qualquer outro país do mundo, tal justaposição denuncia o contraste entre dois modos de vida: aquele que se manifesta na riquíssima estratificação do nosso passado e a imagem nova e brutal que àquela vai se agregando, sem determinar uma nova unidade, mas dando, em toda parte, o sentido de uma penosa e intolerável fratura. A cidade que se justapõe e se sobrepõe à antiga nos aparece como a expressão de um impulso econômico demasiadamente forte para que seja possível conseguir alterar e ordenar os seus movimentos. A caótica expansão obedece às demandas de um imediato e cego interesse privado, e quase nunca encontra acolhimento o apelo por uma predisposição urbanística ordenada, que faça jus aos interesses da comunidade. Ao contrário, a tal propósito, deve-se destacar o sistemático silêncio que acolhe a crítica mais viva no nosso país; tanto é verdade que os poucos combatentes são sempre exortados a desistir da luta, visto que, da outra parte, não há nunca resposta. Vale para todos, como exemplo, o massacre da paisagem italiana que se vai perpetrando por obra de uma instituição pública vinculada ao Ministério das Obras Públicas, ainda que um grande clamor de protestos continue a levantar-se na Itália e no exterior. Mas esta é uma vergonha de tal modo exemplar que merece um discurso à parte!

Ora, o aludido confronto nos induz a colocar o seguinte dilema: se é verdade que existe uma incompatibilidade insuperável entre a velha edilícia e a nova, como têm recentemente afirmado alguns escritores e estudiosos $^{1}$ que reclamam, consequentemente, por uma nítida separação entre a cidade de ontem e aquela de hoje; ou se se trata, ao contrário, apenas de uma negativa condição de espírito, uma espécie de resignação, de difusa ausência de entusiasmo moral por meio da qual nós renunciamos a nos fazermos donos dos instrumentos que nós mesmos criamos.

Que seja conveniente fazer surgir os novos organismos fora dos centros antigos, como novos agregados autossuficientes e dotados de um certo grau de elasticidade expansiva, é coisa óbvia para todo urbanista moderno. Mas aqui se quer considerar a existência do centro antigo como um fato por si próprio, isto é, não como uma proteção passiva que o Estado teria o dever de assumir em nome da arte e da história (e que em realidade não assume), mas como vital sobrevivência em relação a uma efetiva realidade prá- 
tica. Ora, parece-me que, neste sentido, a evocada intangibilidade representa um perfeito absurdo; aliás, exatamente como uma redução ao absurdo, ela fornece um perigoso argumento à tese oposta, que é o seguinte: a partir do momento em que não é possível conservar imutável o ambiente antigo por que o Estado não pode assegurar a conservação de todos os edifícios que possuem interesse artístico e histórico, seria válido demolir tudo aquilo que apresente apenas um caráter ambiental e reconstruir modernamente, sobre o mesmo solo, limitando a conservação aos edifícios de importância excepcional. Ora, este discurso não é apenas a resposta que estão prontos a dar todos os especuladores das áreas públicas e privadas, os chefes dos órgãos estatais e paraestatais e também (permitam-me incluir) a quase totalidade dos arquitetos e dos engenheiros. Isso reflete também a situação real, isto é, o que se está rapidamente realizando, apesar dos indignados protestos e com gravíssimo e irreparável dano a um bem precioso: o valor coletivo da estratificação histórica, o insubstituível fascínio das ruas e das praças dos nossos centros antigos. Como aquilo que se está destruindo é exatamente o patrimônio que a mais moderna experiência de história e de arte contribuiu a colocar em justa evidência, ou seja, o ritmo determinado pelos espaços externos através daquelas formas que transmitem coerentemente o nome de uma particular tradição cultural, e não aquele de um ou outro arquiteto de exceção. Neste sentido, o sentimento que nos inspiram as velhas paredes não é simplesmente uma veleidade romântica, o sonhar uma condição de vida que não pode mais ser reproduzida; pelo contrário, ele nasce do sentir a presença de uma coerência entre vida, arte e artesanato, que parece estar hoje irreparavelmente perdida. Assim, percebemos a sugestão deste mundo diferente como um atributo ambiental que está nos aspectos mais diversos e não apenas em algumas obras singulares; onde a justa consideração de que a maior beleza de uma cidade consista no seu valor de organismo, mais do que nos seus monumentos excepcionais, e que as obras insignes sejam inseparáveis do seu ambiente como da sua respiração. A importância de tal consideração está em reconhecer implicitamente, muito mais do que se fazia em um passado recente, a conexão entre a vida e a arte; a arte como uma condição da própria vida e não como uma realização solitária que se consegue apesar da feiura do mundo circundante. Infelizmente, o que conduz ao erro muitos de nós, arquitetos ou críticos ou historiadores da arte na Itália, está exatamente no nosso desumano e orgulhoso refugiar-se nos fatos estéticos, negligenciando a participação na elucidação e na discussão destes problemas 
2 ROSARIO ASSUNTO, no seu recente escrito Job e Hobby (Civiltá delle macchine, I, 1956) desenvolve interessantes considerações e testemunhos sobre a relação entre lazer e trabalho e sobre a auspiciosa possibilidade que o mundo moderno supere o caráter passivo e constritivo que uma falsa tradição moralista atribuiu, até agora, ao conceito de trabalho.

3 Walter Gropius, Un nuovo capitolo della mia vita, revista Casabella, dez.-jan. 1953-54.

4 Uma ótima experiência italiana, aquela realizada por Giovanni Michelucci com a Bolsa de valores de Pistoia, foi muito frequentemente lembrada porque constitui um caso, infelizmente, tão raro quanto exemplar. da cidade antiga e nova que estão, essencialmente, entre aqueles fundamentais do nosso destino de italianos, pois, por um lado, estão ocupados em esclarecer as nossas conexões com o passado e, por outro, em definir aquilo que ainda hoje parece muito vago e obscuro, ou seja, em que sentido e direção deve ser compreendida a nossa participação em uma civilização comum do mundo moderno.

O maior fascínio dos nossos velhos centros está no testemunho de um modo de vida sábio e ingênuo ao mesmo tempo; de uma economia produtiva que não excluía uma margem de manobra, de conversa e de intimidade ${ }^{2}$. Era uma pobre vida, dotada de pouco conforto, mas conservava um alto valor humano e não é injusto compará-la, com ressalvas, à obsessiva megalópole, que colocou tantos meios à nossa disposição, mas pela qual nos deixamos degradar enquanto homens e que ansiamos abandonar assim que a trégua do trabalho torne possível. Tudo isso (é quase inútil dizê-lo) não pretende significar a condenação da técnica moderna, que é por si só uma grande conquista; quer apenas dizer que ela não basta para nos satisfazer e que o nosso supremo propósito consiste em voltarmos a ser proprietários daqueles meios que a técnica coloca à nossa disposição, de maneira que eles satisfaçam e obedeçam às nossas exigências humanas, nos limites e nos lugares determinados por nós mesmos e não por forças ocultas que fogem ao nosso controle. A tal propósito, gostaria de recordar aqui o modesto e significativo testemunho de um grande pioneiro da arquitetura moderna, Walter Gropius, o qual, em um artigo publicado há três anos, escrevia: "Quando, por exemplo, acusamos a tecnologia e a ciência de terem subvertido os nossos conceitos de beleza e do viver bem, devemos recordar que não é a desconcertante profusão de maquinário técnico para a produção em série que determina o curso dos eventos, mas a vigilância ou a inércia do nosso cérebro que dá ou deixa de dar um caminho a esta evolução"3.

A tese da incompatibilidade entre edilícia nova e antiga se fundamenta, substancialmente, em uma fatalista aceitação do fato concluído, generalizando-o como um dado inevitável e definitivo para as experiências que deverão ser cumpridas no amanhã. Assim, as dimensões das modernas construções e o uso do cimento e do ferro, na atroz banalidade das suas formas correntes, seriam, e não poderiam deixar de sê-lo, a imagem da afirmada incompatibilidade. Aqui está o equívoco de esquecer numerosas experiências positivas de justaposição do novo ao antigo; experiências italianas ${ }^{4}$ e estrangeiras realizadas sem qualquer 
renúncia à modernidade dos materiais e sem recorrer àquele descuido estilístico que ainda impera amplamente entre nós e que a tese da incompatibilidade não faz mais do validar. Lembro os casos positivos de Amsterdam, Frankfurt, Varsóvia; mas aquilo que mais vale a pena considerar são as consequências extremas às quais se produzem se se deseja permanecer coerentemente inconciliáveis: se o novo e o antigo não podem subsistir juntos, significa dizer simplesmente que entre nós e o passado foi produzida uma intransponível fratura; ou seja, que história e tradição de cultura são palavras desprovidas de sentido e que o passado pode apenas nos fornecer motivos de curiosidade arqueológica a partir do momento que ele não serve mais para iluminar o nosso presente. Cabe então aos inconciliáveis responder a esta legítima objeção: se as velhas paredes e as novas paredes não podem coexistir, tampouco poderão coexistir aquelas coisas que nelas encontram uma imagem inevitavelmente coerente.

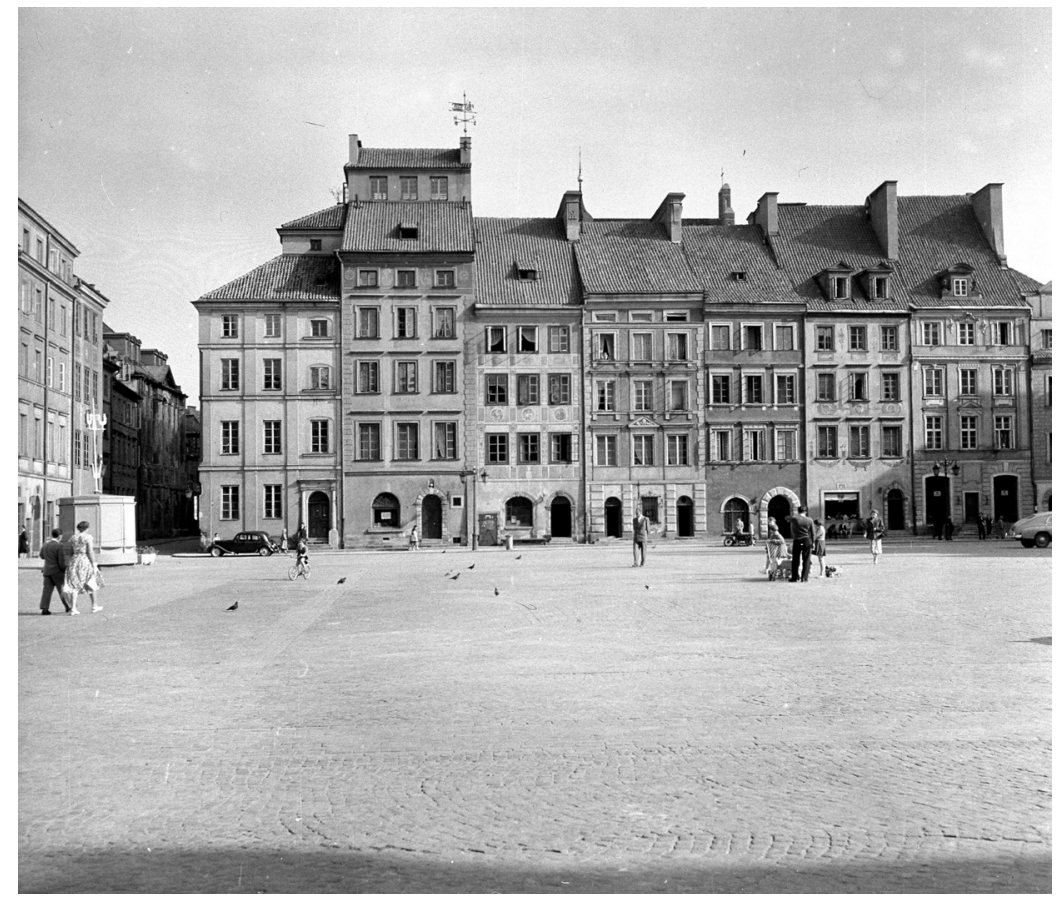

Figura 02

Praça do Mercado de Varsóvia reconstruída após a Segunda Guerra Mundial. Foto de Roberto Pane, final da década de 1950. Arquivo fotográfico Roberto Pane, Dipartimento di Architettura, Università degli Studi di Napoli Federico II, por cortesia de Andrea Pane.

Como esclarecimento daquilo a que me refiro, pode ser útil lembrar da polêmica produzida a propósito do projeto de Wright para o Canal Grande [de Veneza]. Não vou recordar aqui todos os episódios, mas me limitarei aos dados extremos. A quase universal e generosa indignação suscitada pelo anúncio de que uma construção de caráter moderno seria erguida no Ca- 
5 Retomo aqui o conceito fundamental por mim desenvolvido na polêmica que teve lugar, a propósito do projeto de Wright, nas colunas da revista Il Mondo. nal, nesta obra-prima urbanística do passado, nascia, ainda que na mais plena boa-fé, dos usuais lugarescomuns, da costumeira ausência de um sério posicionamento crítico sobre a questão. De fato, enquanto se gritava contra uma significativa expressão moderna, omitiam-se os horrores do falso gótico do qual o Canal é largamente dotado e, similarmente, do falso neobarroco veneziano de uma casa que estava para ser concluída no atracadouro de Sant'Angelo, justamente em pleno agravamento da polêmica. Já a partir desta consideração, parece evidente que a postura da defesa a todo custo, tão sedutora pelo seu sabor de romântica intransigência (mesmo se praticamente insustentável), termina por se tornar reacionária na medida em que fecha os olhos para falsos monstruosos e, portanto, reconhece implicitamente que estes "não incomodam" 5 . Mas só não incomodam àqueles para quem não há diferença entre o gótico autentico e o gótico do século XX, enquanto, para os especialistas, a discrepância é tal que chega ao ultraje; até aquela sensação de desesperada amargura que surge de constatar a própria impotência frente a um mundo dominado pela oficialidade burocrática, distribuidora onipresente de falsificações e substitutivos estéticos e morais.
Figura 03

Projeto elaborado entre 1951 e 1954 por Frank Lloyd Wright para o Memorial Masieri, no Canal Grande de Veneza, que suscitou grande polêmica na Itália dos anos 1950

Fonte: ROGERS, Ernesto N.. Polemica per una polemica. In: Esperienza dell'architettura. Milão: Skira, 1997

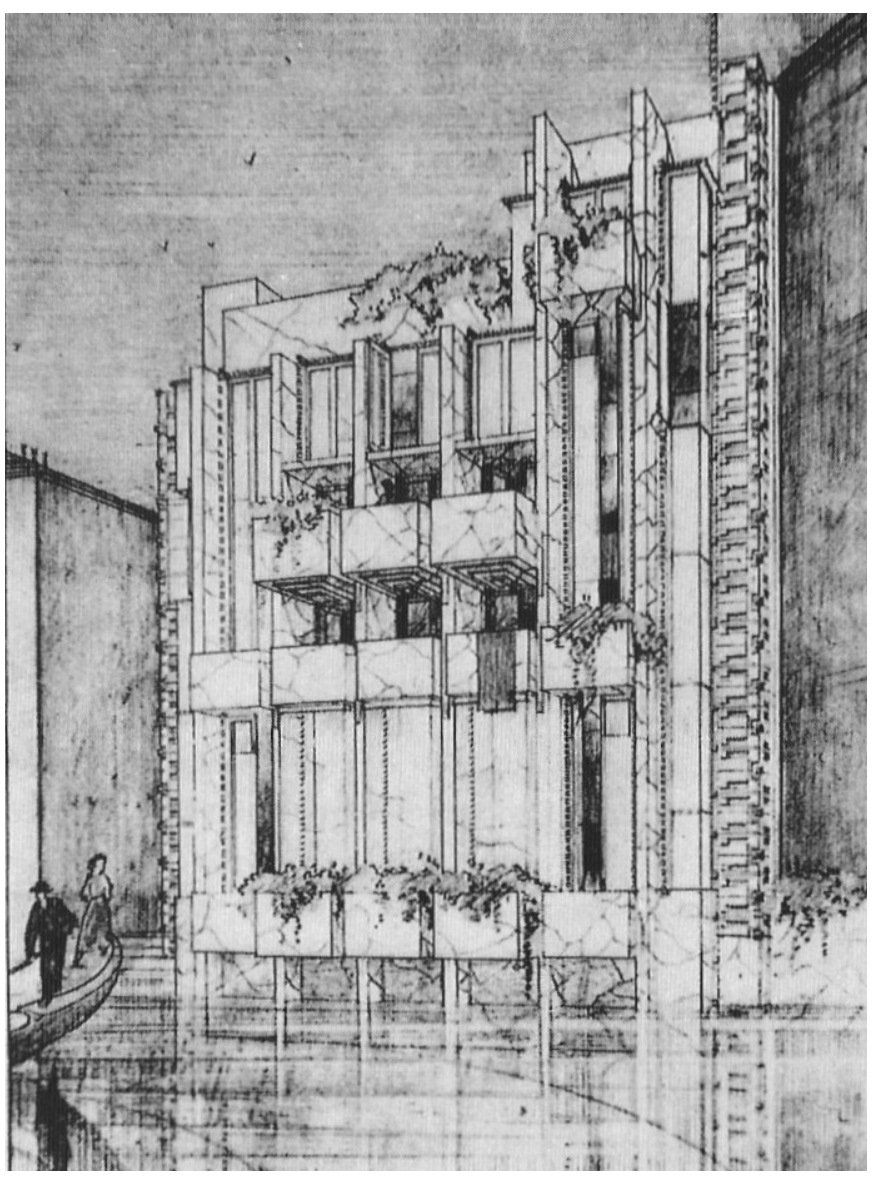


Deve-se ainda acrescentar que o projeto de Wright estava limitado às modestas dimensões da casa à qual a nova construção deveria ter substituído. Com isto, o arquiteto reconhecia como um dado a ser respeitado 6 a relação dimensional do ambiente e, em particular, aquela entre a casa e o contíguo palácio Balbi; em outros termos, aquela relação volumétrica que representa a condição essencial e, ao mesmo tempo, a única possível para a conservação de um ambiente antigo. Dado que é evidente que, excetuando os países nos quais um clima particularmente favorável consente preservar mais ou menos íntegros os originais valores de luz-e-sombra e cromáticos, alhures ocorre que a substituição das pedras externas, em função do seu progressivo desgaste, é feita de modo que, da antiga obra, seja conservada apenas um simulacro mais ou menos fiel; vale para todos o exemplo da Abadia de Westminster, da qual nem uma única pedra externa remonta à primitiva obra gótica; e, de resto, tal é a sorte da arquitetura, a arte que não tem museu, ou melhor, cujo museu não pode deixar de ser o próprio ambiente para o qual ela foi criada ${ }^{7}$.

Mas o que, na tese da intransigência, parece francamente absurdo, é querer, como sinalizei, ignorar a evidente realidade histórica da estratificação que se realizou no passado, configurando, com os seus contrastes, o ambiente que desejamos salvar, e negar que, do mesmo modo, possa e deva ocorrer também no presente. A inserção de formas novas na cidade antiga não poderia deixar de ocorrer mesmo se as normas de proteção e o mais rigoroso respeito fossem observados. Mas para que isto aconteça da melhor maneira é necessário que o ambiente seja percebido como uma obra coletiva a ser preservada enquanto tal; e, portanto, não como integral conservação de uma soma de particularidades, como se entende na conservação de uma edificação única, mas como relação de massas e de espaços que permita a substituição de um edifício antigo por um novo, desde que este esteja subordinado à relação supracitada.

Por outro lado, a uniformidade de vida, como consequência da moderna civilização mecânica, responde a uma visão resignada e pessimista do nosso destino que não encontra justificativas nas extraordinárias realizações atuais do gênio humano, mas apenas em uma redução de aspecto moral; quase como se as conquistas materiais tivessem diminuído, na nossa consciência, o próprio valor da liberdade; e a tal propósito me vem à mente uma imagem que foi tantas vezes retratada: aquela das esgotadas teorias dos operários que se deslocam, todos iguais, em direção às oficinas;
6 Aqui é curioso observar que, do lado oposto ao palácio Balbi, foi recentemente acrescentado, na surdina, um outro pavimento atrás do sótão, sem que se levantasse nenhum protesto.

7 É verdade que insignes fragmentos de arquitetura foram transportados para os museus europeus, principalmente durante o século passado. Pensemos, entre tantos, na estrada babilônica das procissões e na Porta de Mileto, ambas no museu de Berlim; ou então nas portas renascentistas de Cesena e nos inúmeros fragmentos medievais no museu londrino de Victoria and Albert; nos claustros espanhóis e franceses reconstruídos no museu de Fort Tryon em Nova Iorque; todas coisas bastante melancólicas, embora não haja o que dizer àqueles que, para justificar tais formas de genocídio artístico, dizem que quase todas estas relíquias estariam definitivamente desaparecidas, ou reduzidas a ruínas amorfas, se alguém não as tivesse providenciado a sua transferência. 
8 Publicado na revista L'Architettura, setembro 1956, pp. 356-360
9 Architettura e Letteratura, no volume Architettura e arti figurative, Veneza, 1948, pp. 63-71. é uma imagem de ontem, e, ainda assim, a técnica de hoje já a tornou grotesca e absurda, como, de resto, não poucas profecias do marxismo. Portanto, não há razão para crer que uma civilização mais desenvolvida não deva nos enriquecer, no melhor sentido, e, assim, permitir uma maior diferenciação de modos de vida e de costume, e, portanto, tornar, não apenas possível, mas desejável que a cidade nova não destrua aquela antiga, por meio de falsos compromissos e, ao contrário, a ela se justaponha, perpetuando o seu desfrute.

Porém, a esta altura, parece-me oportuno inserir, como exemplo de afirmada incompatibilidade, o testemunho de um recente artigo de Cesare Brandi, Processo all'architettura moderna ${ }^{8}$. 0 autor fala da espacialidade perspéctica renascentista, da invenção perspéctica barroca e do século XIX "exausto e fiel"; ele traça o caminho de um ideal e abstrato urbanismo, exemplificado com uma série de obras primas ambientais e singulares, e conclui afirmando que o espaço da arquitetura moderna "é o mesmo espaço vivido no nosso cotidiano, em geral sem horizonte que não seja barrado por construções, e sem céu que não seja aquele onde voam os aviões". Além disso, ainda que se possa afirmar, graças às obras de alguns notáveis artistas, que exista uma arquitetura moderna, essa "não pode ser inserida em um antigo complexo urbano sem destruí-lo e sem autodestruir-se". Parece-me que o erro desta interpretação está em restringir-se a uma visão estética (estava para dizer estetizante) muito próxima a um esquema, e não histórica, na medida em que fala de arquitetura enquanto arte, omitindo que a cidade, no seu tecido, é feita essencialmente de literatura construída e não de poesia arquitetônica; e, portanto, convido o leitor a outras considerações por mim desenvolvidas e à negligenciada realidade efetiva. Acrescento que, em resposta ao texto de Brandi, Bruno Zevi evidenciou justamente que aqui não se trata de linguagem arquitetônica, mas de programa construtivo: "O rompimento, o massacre é realizado na elaboração do programa edilício e não tem nada a ver com a natureza da linguagem arquitetônica". Mas, a este ponto, é justamente o renovado equívoco entre arquitetura e edilícia que me induz a recordar um texto meu $^{9}$ como algo que talvez possa ainda ajudar a esclarecer.

Recordarei, antes de mais nada, que o equívoco mais comum é produzido pelo uso da palavra arquitetura; palavra que para nós, pela autoridade exercida por uma antiga tradição, continua a significar arte, enquanto nos países anglo-saxônicos ela é sinônimo de edilícia; daí a proposta, já enunciada por alguns, de 
substituir, na linguagem corrente, a segunda palavra à primeira. Além disso, paralelamente à distinção realizada por Croce na sua última estética, na qual na literatura é reconhecido um valor autônomo em relação à poesia, distinguindo a faculdade poética daquela literária ou prática ${ }^{10}$, eu propus uma distinção entre o conceito de arquitetura e aquele de edilícia. Similarmente, de fato, é de se salientar, na primeira, a faculdade poética no seu abandono ao universal, além de todo limite prático; na segunda, a faculdade literária no propósito que lhe é próprio de não perder nunca de vista a razão que é guia e sustentação à realização prática.

A arquitetura é arte quando o é, ou seja, muito raramente. Ao imenso trabalho que se realiza no mundo, edificando e escrevendo, não é normalmente reconhecido um valor diferente daquele que é solicitado e ditado por razões práticas. Com isso, não é de se reconhecer, como frequentemente se fez, um insuperável obstáculo à fantasia na complexidade e urgência das necessidades práticas, mas um caráter distintivo daquelas mesmas necessidades é e quer ser definido; que não quer escondê-las, mas configurá-las em uma forma e esta forma não pode ser a pura e simples expressão da racionalidade.

A distinção entre poesia e literatura arquitetônica encontra a sua melhor confirmação na constatação, já lembrada acima, de que não são os poucos monumentos excepcionais que criam o ambiente das nossas antigas cidades, mas as inúmeras obras inclinadas a exprimir um particular valor coletivo e fornecer, então, a marca peculiar de uma civilização.

Este conceito de literatura arquitetônica foi por muitos acolhido favoravelmente; mas seria benéfico desenvolvê-lo com ulteriores esclarecimentos e exemplos. Aqui me limitarei, não podendo retomá-lo integralmente, a acrescentar apenas a conclusão do meu texto: "A interpretação da arquitetura, no âmbito da expressão literária, enquanto, de uma parte, ajudará a fazer entender historicamente o equívoco do velho formalismo de imitação, satisfará, da outra, a atual exigência difusa de um esclarecimento acerca do caráter estético da arquitetura: não mais rara exceção respeito à qual todo aquele resto é apenas vaga justaposição, mas expressão de civilização e de cultura na qual as práticas exigências assumem característica de uma dignidade humana, calorosa, de acolhedora simpatia. A exceção da poesia arquitetônica continuará a ser possível no seu transcender todo interesse prático. Aos espíritos incapazes de juízo estético, ela parecerá
10 Esses conceitos podem ser pesquisados, como teoria e exemplificação, no volume de CROCE La poesia. 
Deve-se fazer referência, aqui, ao caso de um típico produtor de "ismos", o historiador Pevsner, o qual, como nos informa Zevi, declarou a sua incapacidade em entender esta obra que lhe parece uma espécie de neo-art nouveau. Zevi admirou a coragem demonstrada pelo historiador ao reconhecer esta sua incapacidade; mas não é mais provável que se trate de um modo (espirituoso, segundo Pevsner) de afirmar que a Capela é realmente uma obra malsucedida? absurda, assim como aos mesmos parece hoje absurda a arquitetura de Michelangelo ou de Palladio. Como no passado, ela não obedecerá a qualquer racionalidade ou unidade de medida e, por isso, não será possível predispor a sua criação, nem dizer como é mais conveniente que ela seja. Portanto, ela exprimirá, na coerência única e superior da sua forma, uma sua própria racionalidade e uma sua própria medida".

Assim, querendo citar algum exemplo contemporâneo de poesia arquitetônica, pode-se recordar a casa da Cascata ou a Capela de Ronchamp; e será interessante, e ouso acrescentar também cômico, observar que a segunda provocou a desorientação de todos aqueles que, tendo permanecido fiéis aos esquemas ${ }^{11}$, não puderam acolhê-la como uma nova expressão de liberdade criativa, realizada, com feliz incoerência, justamente por aquele genial arquiteto que, mais que qualquer outro, contribuiu para a difusão dos esquemas racionalistas.

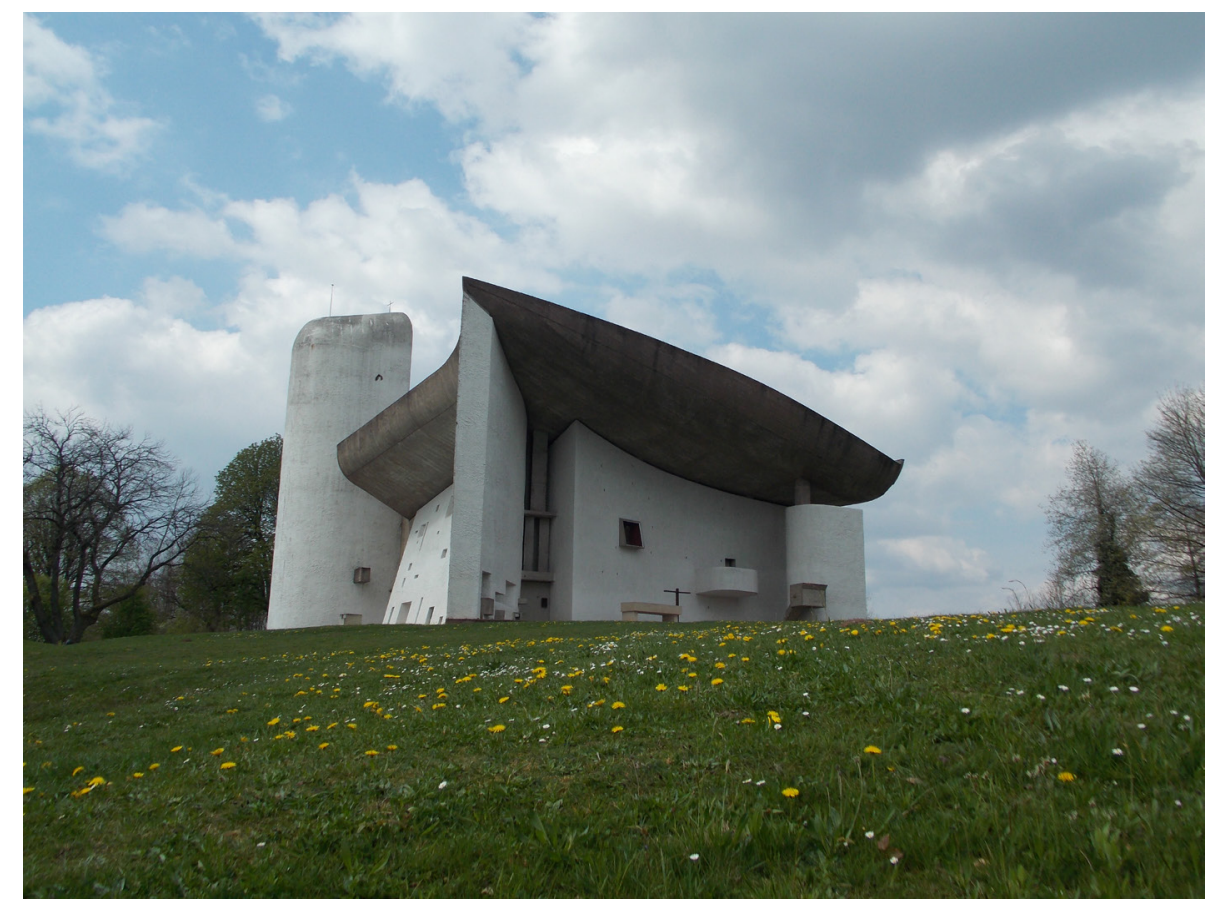

Figura 04

Capela de Notre-Dame-du-Haut em Ronchamp, França, projeto de Le Corbusier (1950-55). Foto realizada por Nivaldo Andrade, abril 2017.

Retornando então, depois dessas divagações e premissas, ao problema da preservação dos centros antigos, parece-me oportuno avançar para uma proposta de caráter geral que poderia ser traduzida em uma norma a ser adotada em âmbito nacional, desde que, e apenas se, obviamente, seja antes elaborada a única lei que, na Itália, se faz extremamente necessária: uma lei que consiga impor o respeito pelas leis. 
Resumo a proposta em algumas informações que, naturalmente, não pretendem ter sido formuladas de maneira definitiva, mas apenas exprimir uma precisa exigência:

- Definir os limites do centro histórico-artístico.

- Estabelecer, sem admitir qualquer exceção, que dentro dos limites supracitados não seja consentido, nem aos entes públicos, nem aos privados, construir edifícios cuja altura supere aquela média dos edifícios circundantes.

- É claro que a caótica especulação não teria tido motivo para considerar o centro antigo como uma mina de ouro se, no lugar de um velho edifício, não tivesse podido construir um outro com, pelo menos, o dobro de sua altura.

- Expropriar, a título de utilidade pública, as zonas verdes privadas incluídas no centro supracitado, impedindo que elas venham a ser exploradas como solo edificante.

Esta última norma é sugerida pela necessidade de evitar que continuem a surgir casas no interior das antigas ínsulas, uma vez que é lá onde a presença secular das hortas e jardins compensava a estreiteza das ruas, fornecendo, às aberturas internas, um precioso respiro ${ }^{12}$.

Procuremos considerar quais objeções poderiam ser feitas a essas propostas. Por exemplo, poder-se-ia dizer que as normas relativas ao dimensionamento das novas construções no centro antigo já estão presentes nos códigos de obra municipais. Então se deve responder que essas, se de fato existem, não são quase nunca voltadas a uma preservação verdadeira e adequada; isso é demonstrado pelo fato que elas permitiram demasiadas "derrogações" e "exceções"; donde a necessidade de condicionar todos os centros histórico-artísticos a uma única norma que atenda ao interesse nacional, aliás, àquele de todo o mundo civil, visto que o interesse municipal demonstrou não saber oferecer uma garantia suficiente.

Além disso, uma fácil objeção pode ser levantada pelo arquiteto ao qual interessar mais a realização do seu pequeno arranha-céu que a conservação do ambiente. Ele pode dizer: nenhuma estética é capaz de demonstrar que o acréscimo de um volume dominante constitua inevitavelmente um dano e não uma contribuição a determinar uma nova e harmônica relação de
12 o dano produzido pelo aproveitamento destes pequenos pulmões verdes é muito grande, apesar de não ser muito visível. Sorrento, apenas para recordar um caso típico, é uma pequena cidade que conserva quase intacto o traçado greco-romano; enquanto se está por completar o plano diretor urbano, a especulação imobiliária se apressa para aproveitar aquelas poucas zonas verdes que restam dentro do perímetro das estreitas vielas. 
conjunto. Com isso, ele vem a negar implicitamente o próprio fundamento da evocada preservação; mas não bastará recordar-Ihe que a conservação das primitivas relações é invocada pela melhor e mais qualificada cultura; dever-se-á, ao contrário, dizer-Ihe que o seu arranha-céu não ficaria só, mas teria imediatamente numerosos e desordenados companheiros; de tal modo que, definitivamente, não lhe restará senão invocar para si próprio, com presunçosa inconsciência, o direito à exceção, e que seja reconhecida definitiva e inalterável a relação entre a sua obra pessoal e o ambiente. Dizia Cellini: um homem como Benvenuto, único na sua arte, não pode ser submetido à lei...

Esta última eventualidade me parece ser tudo, menos hipotética ou rara; e, de resto, é justamente no sentido aludido, isto é, pela ausência de uma responsabilidade, muito frequentemente ignorada, mesmo pelos arquitetos, que aqui se impõe o recurso à autoridade maior do poder executivo. E não me repitam que tal recurso não surte nenhum efeito e que um patrimônio de arte e de cultura se salva somente se todos, e especialmente construtores e projetistas, assumemno e se empenham com paixão na sua defesa. Esta é uma objeção demasiadamente óbvia e teria sido melhor aceitar que cada ambiente seria vituperado e destruído, se fosse necessário esperar a formação de uma consciente responsabilidade pública.

Não se pode, portanto, deixar de recorrer às instituições superiores de proteção, isto é, ao ministério da Educação Pública e àquele das Obras Públicas. A tal propósito, o citado artigo de Brandi conclui com uma frase que é lícito definir como amena; ele declara que não faz sentido acusar os órgãos de proteção artística (ou seja, a direção geral das antiguidades e belas artes à qual eles pertencem), a partir do momento em que a responsabilidade do dano que nos aflige recai sobre todos nós. Nós, ao contrário, temos razão em deplorar que os órgãos supracitados não se demonstrem de fato dispostos a ansiar pela colaboração que o mundo da cultura poderia Ihes oferecer e que eles se limitem a se reconhecer insuficientes nos seus afazeres, justificando-se com a ingerência da classe política

13 A instituição, por mim proposta (Cfr. Bollettino del consiglio nazionale degli architetti, junho 1956), de um colégio de arquitetos selecionados por concurso poderia fornecer, tanto à administração pública quanto aos privados, um instrumento de válida ajuda nas tantas questões que demandam especial cultura e atitude profissional e não apenas experiência administrativa. e com a escassez dos meios disponíveis. Em realidade não é um incremento de meios e de autoridade que melhoraria substancialmente a situação, mas sim um distinto espírito informativo da proteção e, portanto, um distinto ordenamento. Para resumir, uma difícil questão de urbanismo ou de restauração não pode encontrar sua melhor solução na evasão de uma prática de escritório, mas na viva participação ${ }^{13}$ daquelas capacidades que, na maioria das vezes, estão fora dos 
escritórios. A ausência de tal participação faz com que as intervenções das superintendências tenham apenas um caráter negativo e processual e sirvam apenas para retardar (se realmente conseguem) a conclusão dos piores abusos e arbitrariedades. Todo mundo entende, por exemplo, que um edifício antigo pode ser objeto de uma demolição noturna e que a busca pelos responsáveis não trará nenhum resultado, por que os documentos demonstrarão que, apesar da destruição, de modo algum a proteção fracassou: o edifício desapareceu, mas a "prática" Ihe conservará a memória.

Não é menos relevante, por outro lado, a responsabilidade dos órgãos do ministério de Obras Públicas, embora ela apareça menos diretamente comprometida. É notório que os escritórios dos Genio Civile ${ }^{\mathrm{NT} 4}$ dispõem de meios bastante superiores àqueles das superintendências, e que não raramente eles intervêm em matéria de restauro e de urbanismo histórico sem se sentirem minimamente comprometidos com uma colaboração com os órgãos que atuam especificamente nesse campo. Pode-se, ao contrário, dizer que as relações existentes entre esses órgãos, ainda que todos igualmente comprometidos em servir à coisa pública, não sejam muito diferentes daquelas existentes entre os estados dotados de soberania nacional.

Entretanto, apesar das experiências negativas já previsíveis, a nossa atual ação prática não poderá não consistir na renovação de um preciso apelo aos poderes centrais. Por consequência, eu convido o Instituto Nacional de Urbanismo a examinar as supracitadas propostas acerca da defesa dos centros antigos e se, como espero, as considere lícitas, a solicitar aos ministérios interessados que elas sejam imediatamente postas em prática.

Chamo também a atenção do Instituto sobre a já mencionada e mortificante ofensa que se continua a realizar ao decoro público por meio da publicidade rodoviária. Aqui, finalmente, não se trata de um grande problema organizativo, mas apenas de um grande desconhecimento.

Recentemente, alguns semanários noticiaram a decisão tomada pela ANAS ${ }^{\text {NT5 }}$ de uniformizar a publicidade por meio de cartazes, todos com dimensões de dois metros por três e colocados "à guisa de pedra miliar", a cem metros um do outro. Tal novidade será em breve implementada no Norte, com a justificativa de poupar os motoristas do cansaço produzido pelo excessivamente variado e repetido estímulo visual. Atente-se que, em toda essa questão, a ofensa à pai- 
14 Publicado, como número especial da revista, em junho de 1955, e posteriormente reimpresso em volume à parte. Neste sentido, gostaria de lembrar o episódio de um inglês, hospedado na Costa Amalfitana, o qual algum tempo atrás costumava sair à noite para incendiar os engenhos publicitários que prejudicavam a paisagem da esplêndida estrada costeira. Ele já tinha conseguido destruir um pequeno número de engenhos quando foi, infelizmente, identificado e condenado a pagar pelo prejuízo.

15 Para isso teria sido necessário que tivéssemos levado em conta as trágicas experiências de nossa recente história, ao invés de nos submetermos a uma involução na qual, travestida de uma democracia municipal, sobrevive imperturbável a velha e deplorada retórica. sagem, reforçada pelos prometidos cartazes de seis metros quadrados, não é nem ao menos levada em consideração; nem, que eu saiba, este órgão, cuja autonomia frente ao decoro do país pode ser dita como sendo verdadeiramente exemplar, sentiu até agora a necessidade de responder às acusações que Ihe foram feitas em toda parte, na Itália e no exterior. Ora, como se pode esperar alcançar qualquer resultado nas ainda mais árduas e problemáticas questões de planejamento intermunicipal e regional, se não se consegue, não digo superá-la, mas nem ao menos ter uma resposta em uma tarefa que, além de tudo, nos desonra aos olhos do mundo? Se pensamos que, na Inglaterra, se desenvolveu, no ano passado, uma violenta campanha por iniciativa da Architectural Review por algo muito mais modesto e que, ainda, nenhum de nós, com os tempos que correm, ousaria julgar intolerável, ou seja, as sinalizações rodoviárias em pleno campo, os semáforos, o cartaz keep left, os postes, os fios de eletricidade etc. Resumindo, tudo aquilo que tende a uniformizar "toda a área rural inglesa a subúrbio", como escreve Ian Nairn, o autor do ótimo volume ${ }^{14}$ que tem como título Outrage (Ultraje). A iniciativa inglesa obteve o consenso e o encorajamento de toda a imprensa, do Times ao Daily Mirror. Mas, a bem da verdade, também entre nós a participação da imprensa foi unânime e nem por isso o ministro das Obras Públicas se sentiu na obrigação de intervir ordenando à ANAS a suspensão dos contratos de publicidade e a remoção das respectivas feiuras; ou, talvez, não o tenha feito porque o órgão é a tal ponto autônomo a ponto de poder se dizer dotado de poderes soberanos? O Instituto Nacional de Urbanismo não poderia intervir com sua autoridade para que fosse oferecida ao menos uma explicação?

Parece-me que o referido esclarecimento acerca do conceito de literatura arquitetônica poderia ser útil especialmente na Itália, onde, ao invés de perseguir o mais modesto caminho da probidade, obstina-se muito frequentemente a enveredar pela fantasia.

A fonte das maiores desventuras na nossa moderna edilícia é, de fato, aquilo que se poderia definir de equívoco artístico. Equívoco do recente passado que sobrevive imutável no nosso presente por não ter sido completada aquela evolução cultural que, sozinha, teria podido evitar a subsistência da antiga academia, apesar da revolução dos meios materiais colocados à nossa disposição. Em outras palavras, não foi suficiente, nem poderia ter sido, a disponibilidade dos novos instrumentos para que as nossas disposições criativas se renovassem seja por dentro, seja por fora ${ }^{15}$. 
A tendência geral à ênfase demonstrativa, a intenção de alcançar a maior visibilidade possível; em resumo, a ausência de discrição e de modéstia são as características mais difundidas e imediatamente reconhecíveis da nossa edilícia; e são, repito, apesar das aparências, características imutáveis. Eis, por exemplo, a maldição das geniais soluções plásticas e cromáticas com as quais, exatamente como outrora, fazemos todos os esforços para que se perceba a nossa presença como inventores de uma nova arquitetura (que talvez chamaremos nuclear); e, muito frequentemente, é suficiente apenas uma solução genial para arruinar toda uma via que, antes, possuía uma sua estratificação orgânica e uma sua beleza. Um indivíduo pintou de bleu ou de vermelho as saliências de todos os balcões de uma casa de muitos pavimentos; ele está certo de ter feito algo original, a partir do momento em que aquilo nunca havia sido visto antes. Na realidade, a sua casa produz em nós o mesmo efeito da rádio do nosso vizinho quando funciona a pleno volume, enquanto desejaríamos poder nos recolher ou dormir em paz.

Similarmente, um conjunto de casas modernas como aquele que se pode ver na periferia de qualquer uma das nossas cidades pode ser comparada a uma nossa discussão pública. De fato, nem nos ambientes mais qualificados se realiza, entre nós, aquela recíproca subordinação que deveria consentir a cada um manifestar o próprio ponto de vista. Existirão sempre alguns que tentarão se impor com a própria eloquência, com o maior volume da própria voz, e, por outro lado, alguns outros constrangidos ao silêncio por timidez, escrúpulo excessivo ou insuficiência de prestígio, mesmo tendo, talvez, muitas e mais coisas úteis a serem ditas.

Bastariam estas poucas considerações e confrontos para entender como as maiores dificuldades que se opõem na Itália a um urbanismo sério não são de natureza técnica; ou melhor, que antes de o serem, são de natureza moral e psicológica.

Hoje, o cimento e o aço permitem a fácil realização de massas edificadas tão fortemente concentradas a ponto de promover condições de convívio que nem mesmo o espírito mais otimista pode considerar favoráveis a um harmônico desenvolvimento das novas gerações. Os pretextos da extrema urgência e da mais rígida economia, em um país de alto crescimento demográfico (a nossa maior e mais tácita tragédia) determinaram, nesse pós-guerra, a frustação de qualquer saudável propósito urbanístico mediante o desfrute acidental e caótico das áreas edificáveis; e 
nesta iniciativa as instituições estatais e paraestatais se demonstraram, não raramente, mais cegas e avarentas que os especuladores privados.

Mas tudo isso, dir-se-á, tem ainda sabor de vaga e genérica recriminação. Isso pode ser verdade, mas o discurso se fará mais preciso (e, ousarei acrescentar, insólito) se, como arquitetos, nos colocarmos frente à nossa bem definida responsabilidade. Estamos, por exemplo, absolutamente convencidos que as dimensões estabelecidas nas edificações que projetamos são aquelas justas? Não é talvez verdade que a atribuição que nos é imposta pela sociedade é aquela de ser especialistas da densidade e de conferir às aglomerações organizadas uma aparência estética? É preciso ter uma forte dose de presunção e de cinismo para acreditar que esta edificação de oito, dez ou doze pavimentos, por nós desenhada e posta a destruir um ambiente já orgânico, na sua relação entre construções e natureza, seja uma expressão positiva de literatura construída (se não verdadeiramente de poesia) e não mais algo ao qual nós acabamos de conferir uma marca irrealista, enquanto a sua realidade, naquele significado econômico e social que realmente importa, já estava preparada por outros? Quem pode seriamente acreditar que aquele desenho específico de balcão, aquele específico detalhe tenha uma importância tal, a ponto de transcender a fugacidade da moda, e não esteja, ao contrário, destinado a ser causa de íntima mortificação e cansaço para seu autor quando, passados apenas alguns anos, a moda terá sugerido, como a feiticeira Circe, novos comportamentos não menos extrínsecos e falsamente persuasivos?

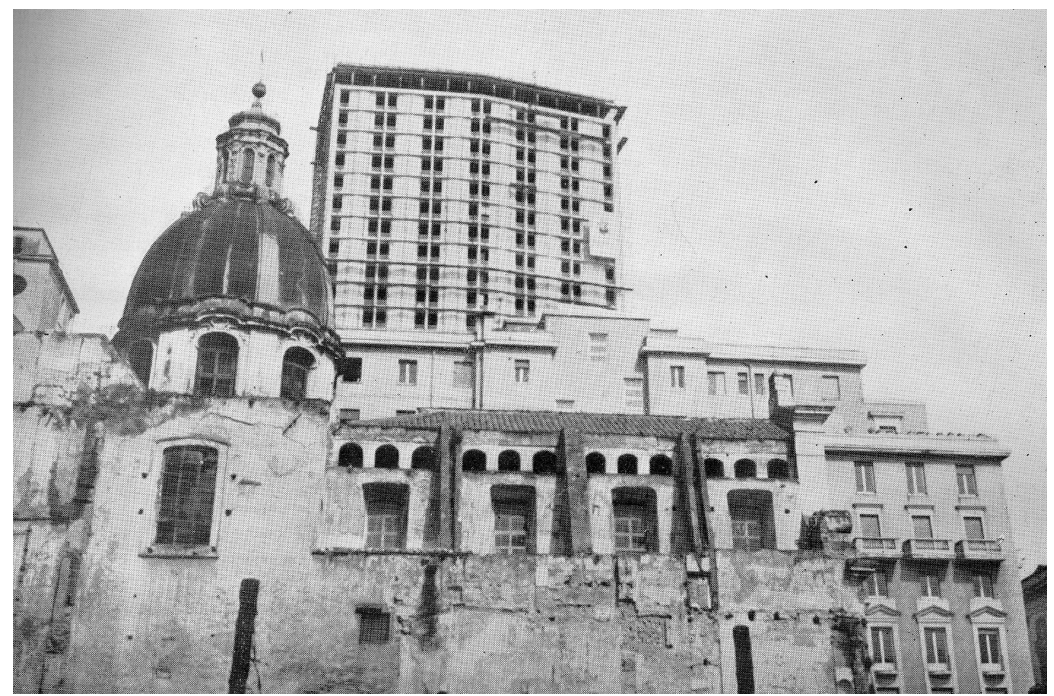

Figura 05

Piazza del Mercato em Nápoles. Em primeiro plano veem-se as ruínas de uma antiga construção. Ao fundo, o gigantesco Palazzo Ottieri, construído em 1958. (Foto de Roberto Pane provavelmente realizada durante ou logo após a construção do Palazzo Ottieri. Fonte: Documento su Napoli. Nápoles-Milão: Edizioni di Comunità, 1958.) 
Por outro lado, as exorbitantes dimensões que produzem uma tão grave densidade humana não constituem uma inevitável consequência do progresso técnico, mas tão somente um caso limite de investimento econômico; por que é evidente que os meios de comunicação já à nossa disposição e as grandes conquistas que vão delineando uma verdadeira e própria revolução na nossa vida em sociedade, como as novas fontes de energia e a automação, permitem uma descentralização que já faz parecer absurda e anacrônica a concentração da nossa megalópole. Frente à rapidez das transformações que a moderna técnica sugere, seriam mais necessários organismos de fácil adaptabilidade e transformação do que os gigantescos falanstérios em cimento e aço ${ }^{16}$.

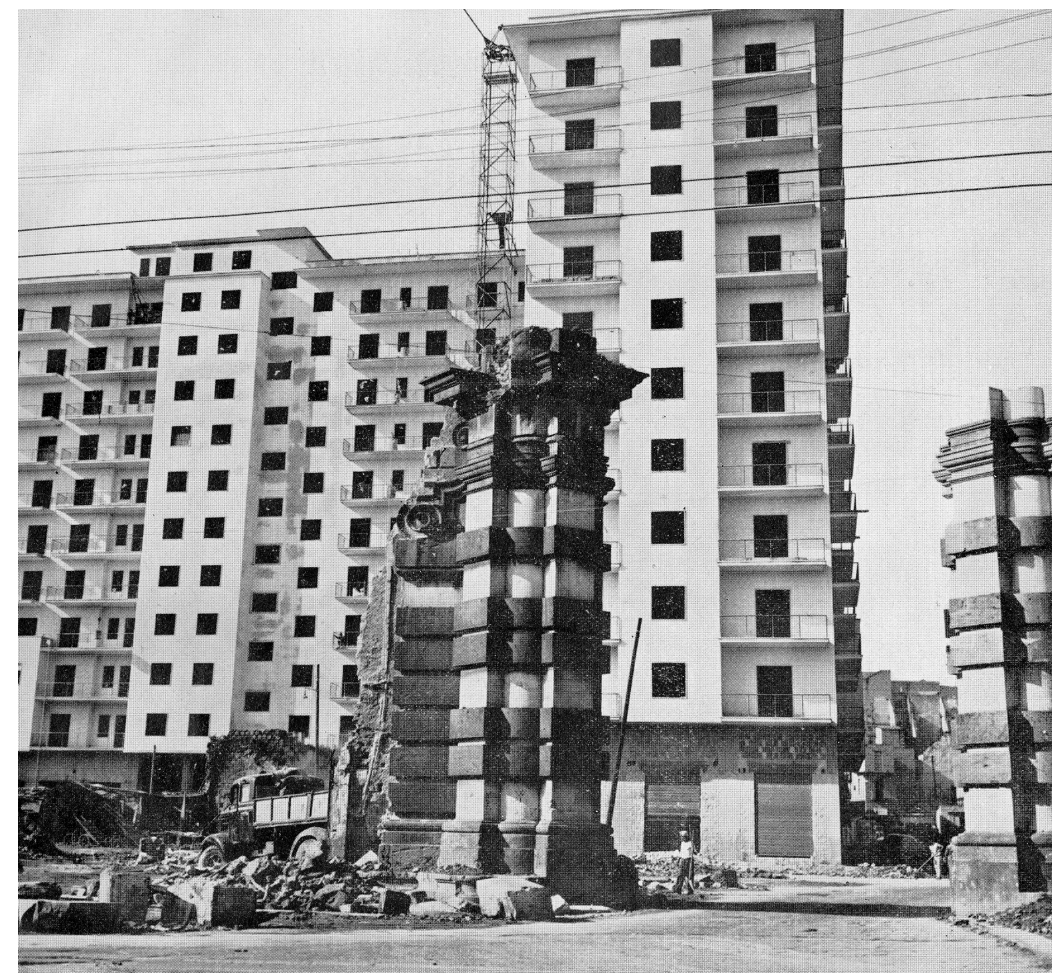

Figura 06

Piazza del Mercato em Nápoles. Em primeiro plano veem-se as ruínas de uma antiga construção. Ao fundo, o gigantesco Palazzo Ottieri, construído em 1958.

(Foto de Roberto Pane provavelmente realizada durante ou logo após a construção do Palazzo Ottieri.

Fonte: Documento su Napoli. Nápoles-Milão: Edizioni di Comunità, 1958.)

Mas este é, talvez, um tom já excessivamente elevado para comentar aquilo que está acontecendo na Itália, onde o aumento da densidade de habitação no centro antigo é muito mais um ato de verdadeira e efetiva criminalidade contra o interesse público do que uma questão de natureza técnica. Assim, em Nápoles, estão sendo construídos arranha-céus sem que seja realizado qualquer desbastamento prévio ${ }^{\mathrm{NT6}}$, mas apenas au-
16 Como máxima documentação crítica do drama urbanístico moderno, através de uma visão não estritamente tecnicista, mas histórica e humana, merece ser objeto de reflexão o livro de Lewis Mumford, The culture of cities, Londres, 1938, e especialmente, no sentido acima mencionado, o capítulo intitulado $L a$ insensata cittá industriale. 
mentando, para maior riqueza de algum abjeto especulador, o já paroxístico tráfego e a infeliz convivência.

$\mathrm{O}$ arquiteto deve conquistar a possibilidade de determinar, sem obediências forçadas e constrangimentos desumanos, a relação entre o novo e o antigo e a criação, orgânica e não adicional, de um novo ambiente. "Os nossos bairros residenciais, escreve ainda Gropius, têm frequentemente apenas um certo número de casas e de ruas, reunidas com certo critério adicional e privadas daqueles elementos comunitários que poderiam transformar um aglomerado de habitações em um organismo vivo, racionalmente limitado e de justas proporções. Carecem totalmente daquele fermento traduzido pelos valores intangíveis de uma projetação criativa e de uma concepção orgânica, que dão à vida o seu sentido mais profundo e para os quais o passado nos deu tão esplêndidos exemplos de unidade". Mas isso também, se fará objeção, não é certamente novo. Não há apelo à funcionalidade, ao íntegro organismo, à viva sociabilidade que na Itália já não tenha sido lançado mil vezes. Isso não evita, porém, que a nossa verdade continue a estar sempre alhures, e que se reflita em uma edilícia falsamente estetizante e renunciante, imagem do nosso hábito social e político, testemunho de um "saber fazer" temperado por sorrisos céticos e por piadas, assim como ocorre na atividade de qualquer outro campo profissional. Bastará pensar no quadro que Roma hoje oferece ao mundo (para citar apenas o exemplo mais gritante) para que não seja necessário acrescentar mais nada.

Cada um de nós percebeu, na Itália, a admiração por alguns conjuntos recentemente construídos nos países escandinavos, na Holanda ou alhures, como coisas que não revelavam propriamente um desenho rico de fantasia, mas eram, no entanto, plenamente aceitáveis pela sua estudada e feliz execução e pela pesquisa de uma ambientação natural. Algo semelhante, aliás, mais significativo, se verificou nesses últimos tempos no confronto direto entre a nossa produção nas Trienais de Milão e aquela de alguns países do Norte. A nossa, apesar das esporádicas qualidades inventivas, improvisada e dispersiva; aquela estrangeira, por sua vez, refletida e contida. Na nossa, as experiências passadas parecem não ter ensinado nada porque sempre se recomeçou do início, enquanto naquelas estrangeiras o discurso parece retomar um outro precedente, cujo ensinamento se procurou aproveitar.

Para oferecer, em síntese, a imagem da nossa edilícia, pode-se dar uma olhada nos seus aspectos ex- 
tremos, ou seja, por um lado, ao ostentado luxo das edificações de dois ou três milhões por vão e, por outro, à vergonhosa insuficiência da edilícia que poderíamos chamar de proletária. No meio disso tudo, o espetáculo mais miserável é aquele oferecido pela perspectiva de casas populares, nas quais o projetista, no rastro do mencionado equívoco estético, procurou fazer da arquitetura inspirada em Mondrian (ou em alguém em seu lugar), justapondo impossíveis planos geométricos e forçando, em uma árida composição abstratizante, a elementar necessidade dos cheios e dos vazios. A irônica representação do quadro pode ser completada inserindo-se um observador: o obscuro habitante que se move, estranho e anônimo entre estas formas, percebendo apenas a precoce decadência e não a metáfora mecanicista; metáfora que, mais ou menos mal digerida, fornece hoje uma provisória e irônica afinidade entre os mais remotos países. Dado que, entre os requisitos surpreendentes do nosso presente, é de se registrar a extrema rapidez e facilidade com que uma nova ideia figurativa dá a volta ao mundo e produz, em qualquer lugar, imitadores e prosélitos. Já há muito anos, de fato, Le Corbusier amaldiçoava os muitos imitadores da nova arquitetura, que arriscavam arruinar um Renascimento na sua aurora, une Renaissance à ses débuts $^{17}$.

Talvez não se tenha entendido suficientemente que uma verdadeira e real renovação da nossa edilícia não poderia consistir em um requisito de caráter técnico ou em um diferente caminho formal, entendido em si mesmo como possuidor de um destino autônomo. A nossa edilícia se renovará se nós, arquitetos, combatermos enquanto partícipes e responsáveis por um mundo comum, de onde contribuir para mudar aquelas condições de vida social, política e administrativa das quais depende unicamente a nossa atuação e que sabemos ser hoje desfavoráveis a um promissor desenvolvimento do nosso ambiente. Em outras palavras, é necessário comprometer-se, mesmo sob o risco de desagradar aos órgãos do poder executivo, às instituições do Estado onipotente, criticando-os onde couber (e Deus sabe se cabe) os equivocados ordenamentos e procedimentos e sugerindo novas possibilidade e novos caminhos. É necessário perceber que o maior perigo da sociedade moderna, esteja ela dominada pela direita ou pela esquerda, está na estatolatria, no poder cego e indiferente das pesadas organizações contra as quais muitos homens iluminados defendem hoje a atuação de limitadas comunidades autônomas, nas quais o
17 Cf., sobre as teorias de Le Corbusier, o meu texto Le Corbusier e le tendenze meccanicistiche dell'architettura moderna, em Architettura e arti figurative, Veneza, 1948. 
18 Architettura d'oggi, coleção do Viesseux, II, p. 13. Apesar das reservas e objeções de natureza crítica que foram feitas a Nervi, eu considero o seu volume Costruire correttamente como a mais viva contribuição dada nestes anos aos problemas relacionados à preparação cultural das faculdades de arquitetura na Itália. poder esteja subdividido, ao invés de provir da distância e do alto. Como exatamente escreve Simone Weil, o perigo atual é que as antigas formas de ditadura sejam, pouco a pouco, substituídas pela colossal e anônima "opressão da função". 18

Ora, aqueles que creem serem estes discursos estranhos ao urbanismo são, eles próprios, estranhos a uma concreta realidade e cultura; e, de resto, em nome de que, se não de uma real capacidade de síntese, e então de uma reponsabilidade mais vasta e aberta, o arquiteto moderno poderia aspirar a chamar-se urbanista se a sua intervenção, como consequência de outras complexas pesquisas e demandas, não se deverá limitar a um aparato estético que respeite o bom gosto, mas deverá, ao contrário, interpretar e resolver as exigências de uma melhor convivência? É necessário, portanto, que ele sinta, ainda mais que os outros, o dever de uma plena participação na vida social e política.

A quem afirma que a nossa função de arquitetos deve ser limitada à solução técnica dos problemas que nos são postos pelos outros, gostaria de dedicar, para que seja objeto de reflexão, a seguinte página de C. G. Jung: "Quanto maiores as organizações, tão mais inevitáveis lhe são a imoralidade e a cega estupidez. Se agora a sociedade, nos seus representantes individuais, afirma já automaticamente as qualidades coletivas, ela premia de tal modo cada mediocridade, todos aqueles que se dispõem a vegetar de maneira cômoda e irresponsável: é inevitável que o elemento individual seja colocado à parte. Este processo começa na escola, continua na universidade e domina onde quer que o Estado ponha a sua mão. Quanto menor é o corpo social, mais garantida é a individualidade dos seus membros, maior a sua relativa liberdade e, portanto, a possibilidade de uma responsabilidade consciente. Sem liberdade não pode existir moralidade. A nossa admiração pelas grandes organizações desaparece se percebemos o outro aspecto do milagre, isto é, o monstruoso acúmulo de todas as características primitivas do homem e o inevitável aniquilamento da sua individualidade em favor daquele monstro que é qualquer grande organização. Um homem de hoje, que corresponda mais ou menos ao ideal moral coletivo, fez do seu coração um covil de assassinos, como não é difícil demonstrar através da análise do seu inconsciente, mesmo que ele não seja efetivamente perturbado. Se está normalmente inserido no seu ambiente, não o perturbarão nem mesmo as piores atrocidades da sua sociedade, dado que a maioria dos seus concidadãos acredita na alta moralidade das suas organizações sociais" . 
Essas palavras de Jung poderiam ser invocadas pelo Movimento italiano de Comunidade como um enérgico testemunho a favor dos limitados organismos de vida associativa que por ele é eficazmente defendido. A tal propósito, convido o leitor a um texto de U. Serafini no qual se encontram felizes observações a serem consideradas naquela problemática do planejamento intermunicipal e regional que ainda espera ser devidamente enunciada. Recomendo, por exemplo, esta passagem: "Na sua tradução industrial, como observa Petit, o planejamento do território consiste em colocar as indústrias lá onde são úteis aos homens, ao invés de colocá-las onde produzem, para os seus proprietários, os maiores e imediatos lucros". E aqui vem a vontade de questionar: onde se colocariam as indústrias dos planos regionais italianos? É possível que elas estejam lá onde convém à utilização pelos homens, em um país como o nosso, no qual são ainda monopólio privado os armazéns gerais, a energia elétrica e as telefônicas?

Concluindo, parece-me que nós, arquitetos, devemos possuir uma consciência mais precisa da história contemporânea do nosso país, de maneira que ela se torne condição concreta, e não caprichosa e abstrata, da nossa atuação. Não existe outro caminho para nos libertarmos daquele provincialismo que continua a nos afligir, apesar da nossa vitalidade e das nossas qualidades brilhantes. Outras obras, aquelas amadurecidas sob um clima diferente e por uma sociedade diferente, não são coisas a serem imitadas, mas apenas a serem compreendidas como testemunhos da múltipla variedade na qual se configura a liberdade criativa.

O que falta em nós não é a possibilidade de indicar alguns exemplos felizes, mas uma produção média que seja aceitável e digna; uma vez que, repito, uma civilização bem-sucedida não poderá ser demonstrada por algumas obras de poesia, mas por uma difusa literatura arquitetônica que encontre lugar ao lado daquela do passado.

\section{NOTAS DO TRADUTOR:}

\footnotetext{
NT1 Nota do Tradutor (NT): Este ensaio foi apresentado originalmente por Roberto Pane no VI Congresso Nacional de Urbanismo, realizado em Turim entre 18 e 21 de outubro de 1956, sendo publicado nos anais do congresso no ano seguinte. (PANE, Roberto. Città antiche edilizia nuova, Congresso nazionale dei urbanistica (Torino, 18-21 ottobre 1956), in pianificazione intercomunale. Atti del congresso, INU, Roma 1957, pp. 451-469). A presente tradução foi realizada a partir de uma outra edição, datada de janeiro de 1957 (PANE, Roberto. Città antiche edilizia nuova. Nápoles: Università degli Studi di Napoli / Facoltà di Architettura, 1957). Sua publicação no Brasil, poucos meses após se completarem 30 anos da morte de Roberto Pane, pretende contribuir para a difusão sobre o seu pensamento.
} 
NT2 O tradutor agradece ao Prof. Giulio Pane, docente aposentado da Università degli Studi di Napoli Federico II e filho de Roberto Pane, pela concessão do direito à tradução deste texto, e ao Prof. Andrea Pane, da Università degli Studi di Napoli Federico II e neto de Roberto Pane, pela localização e autorização para utilização das imagens originais que ilustram esse texto. Deve-se destacar que o texto original de Roberto Pane não apresentava imagens de qualquer espécie e que a decisão de ilustrá-lo com fotografias realizadas pelo próprio Pane (e também pelo tradutor) é de responsabilidade exclusiva do tradutor. O tradutor agradece também a colaboração de Raquel Neimann, Maria Emília Regina e Marcella Sgura, que, na condição de alunas da disciplina ARQ512 - Centros Históricos, do Programa de Pós-Graduação em Arquitetura e Urbanismo (PPG-AU) e do Mestrado Profissional em Conservação e Restauração de Monumentos e Núcleos Históricos (MP-CECRE) da Universidade Federal da Bahia (UFBA) nos semestres 2014.1 e 2015.1, colaboraram de forma decisiva na tradução deste texto, bem como ao Prof. Federico Calabrese pela revisão final.

NT3 Estes dois parágrafos em itálico correspondem a um acréscimo ao texto original de 1956, que só é encontrado nas versões de 1957 e de 1959.

NT4 O Genio Civile é um órgão público que, na Itália, tem a função de controlar, monitorar e executar as obras públicas, a nível local.

NT5 A ANAS (Azienda Nazionale Autonoma delle Strade, em português Agência Nacional Autônoma de Rodovias) foi uma organização de direito privado criada em 1946 para gerenciar a rede de estradas e autoestradas italianas, sob a supervisão técnica e operacional do Ministério da Infraestrutura e dos Transportes.

NT6 No original, diradamento. Adotamos o termo "desbastamento" na tradução, seguindo a escolha de Cabral e Andrade (CABRAL, Renata Campello; ANDRADE, Carlos Roberto Monteiro de. "Roberto Pane, entre história e restauro, arquitetura, cidade e paisagem. Entrevista com o arquiteto Andrea Pane". Risco: Revista de Pesquisa em Arquitetura e Urbanismo (on line), n.15, 2012, p. 107-108). Deve-se destacar que, assim como no título deste ensaio, ao adotar o conceito de "desbastamento construtivo", Roberto Pane faz referência ao pensamento de Gustavo Giovannoni. 